\title{
Monitoring cyanobacterial toxins in a large reservoir: Relationships with water quality parameters
}

\author{
Seenivasan Subbiah ${ }^{1}$, Adcharee Karnjanapiboonwong ${ }^{1}$, Jonathan D Maul $^{1}, \operatorname{Degeng}_{\text {Wang }}{ }^{1}$, Todd A Anderson $^{\text {Corresp. } 1}$ \\ 1 Department of Environmental Toxicology, Texas Tech University, Lubbock, United States \\ Corresponding Author: Todd A Anderson \\ Email address: todd.anderson@ttu.edu
}

Cyanobacteria are widely distributed in fresh, brackish, and ocean water environments, as well as in soil and on moist surfaces. Changes in the population of cyanobacteria can be an important indicator of alterations in water quality. Metabolites produced by blooms of cyanobacteria can be harmful, so cell counts are frequently monitored to assess the potential risk from cyanobacterial toxins. A frequent uncertainty in these types of assessments is the lack of strong relationships between cell count numbers and algal toxin concentrations. In an effort to use ion concentrations and other water quality parameters to determine the existence of any relationships with cyanobacterial toxin concentrations, we monitored four cyanobacterial toxins and inorganic ions in monthly water samples from a large reservoir over a 2-year period. Toxin concentrations during the study period never exceeded safety limits. In addition, toxin concentrations at levels above the limit of quantitation were infrequent during the 2-year sampling period; non-detects were common. Microcystin-LA was the least frequently detected analyte (86 of 89 samples were $N D)$, followed by the other microcystins (microcystin-RR, microcystin-LR).

Cylindrospermopsin and saxitoxin were the most frequently detected analytes. Microcystin and anatoxin concentrations were inversely correlated with $\mathrm{Cl}^{-} \mathrm{SO}_{4}{ }^{-2}, \mathrm{Na}^{+}$, and $\mathrm{NH}_{4}{ }^{+}$, and directly correlated with turbidity and total P. Cylindrospermopsin and saxitoxin concentrations in water samples were inversely correlated with $\mathrm{Mg}^{+2}$ and directly correlated with water temperature. Results of our study are expected to increase the understanding of potential relationships between human activities and water quality. 
1 Monitoring cyanobacterial toxins in a large reservoir: Relationships with water quality

2 parameters

3 Seenivasan Subbiah ${ }^{\dagger}$, Adcharee Karnjanapiboonwong ${ }^{\dagger}$, Jonathan D. Maul ${ }^{\dagger}$, Degeng Wang ${ }^{\dagger}$,

4 Todd A. Anderson*广

5 Department of Environmental Toxicology, Texas Tech University, Box 41163, Lubbock, TX

679409 , USA

\section{7 *Corresponding Author:}

8 Todd A. Anderson

9 Department of Environmental Toxicology

10 Texas Tech University

11 Box 41163, Lubbock, TX 79409, USA

12 Email: todd.anderson@ttu.edu

13 Phone: 806-834-1587 


\section{Abstract}

Cyanobacteria are widely distributed in fresh, brackish, and ocean water environments, as well as in soil and on moist surfaces. Changes in the population of cyanobacteria can be an important indicator of alterations in water quality. Metabolites produced by blooms of cyanobacteria can be harmful, so cell counts are frequently monitored to assess the potential risk from cyanobacterial toxins. A frequent uncertainty in these types of assessments is the lack of strong relationships between cell count numbers and algal toxin concentrations. In an effort to use ion concentrations and other water quality parameters to determine the existence of any relationships with cyanobacterial toxin concentrations, we monitored four cyanobacterial toxins and inorganic ions in monthly water samples from a large reservoir over a 2-year period. Toxin concentrations during the study period never exceeded safety limits. In addition, toxin concentrations at levels above the limit of quantitation were infrequent during the 2-year sampling period; non-detects were common. Microcystin-LA was the least frequently detected analyte ( 86 of 89 samples were ND), followed by the other microcystins (microcystin-RR, microcystin-LR).

Cylindrospermopsin and saxitoxin were the most frequently detected analytes. Microcystin and anatoxin concentrations were inversely correlated with $\mathrm{Cl}^{-}, \mathrm{SO}_{4}^{-2}, \mathrm{Na}^{+}$, and $\mathrm{NH}_{4}{ }^{+}$, and directly correlated with turbidity and total P. Cylindrospermopsin and saxitoxin concentrations in water samples were inversely correlated with $\mathrm{Mg}^{+2}$ and directly correlated with water temperature. Results of our study are expected to increase the understanding of potential relationships between human activities and water quality.

Key words: freshwater lake, algal toxins, water quality 


\section{Introduction}

Anthropogenic pollution of freshwaters has altered microbiota, leading to changes in their functions, deterioration of water quality, and economic loss (Carpenter et al. 1998). Algae are a vital group in aquatic ecosystems and a significant factor for monitoring water quality. Algae are important indicators of ecosystem conditions because of their quick response to physicochemical changes in freshwater systems. Loading of inorganic nitrogen $(\mathrm{N})$ and phosphorous $(\mathrm{P})$ nutrients in aquatic systems contributes to increasing rates of cyanobacterial hazardous algal blooms (cHABs). Negative effects of cyanobacterial toxins in rats, mice, and fish, as well as their detection in blue-green algae food supplements have been reported (Kondo et al. 1996; Bruno et al. 2006; Drobac et al. 2016). The economic loss due to cHABs in the United States are annually estimated at more than one billion dollars (Dodds et al. 2009). Human-induced eutrophication and subsequent algal blooms negatively impact recreational water use, waterfront property values, threatened and endangered species, and drinking water.

Data from the Harmful Algal Bloom-Related Illness Surveillance System (HABISS) from 2007-2011, which were summarized in Backer et al. (2015) indicated that, among 2323 samples, cyanobacteria (73\%) was the most common type of organism reported followed by Anabaena spp. (20\% of samples), Aphanizomenon spp. (7\% of samples), and Microcystis spp. (7\% of samples). There are some reports available on factors affecting cyanobacterial growth (Robarts and Zohary, 1987). These include: effects of temperature on algal growth (Butterwick et al., 2005), nitrate uptake capabilities of cyanobacteria (Flores et al., 2005), effects of temperature on algal distribution (Breitbarth et al., 2007), temporal variations in the photosynthetic activity of cyanobacteria species (Hodoki et al., 2011), and the influence of N, P, and other environmental factors on algal blooms in freshwater and marine systems (Paerl, 2008). Gobler et al. (2016) 
61 reported reductions of $\mathrm{N}$ and $\mathrm{P}$ were essential to reducing the intensity and toxicity of algal

62 blooms in Lake Erie, however, Harke et al. (2016) suggested that blooms in western Lake Erie

63 were not significantly reduced as a result of $\mathrm{P}$ nutrient management plans. Reports are also

64 available on cyanobacterial toxins in lakes, reservoirs, and recreational sites in other countries

65 (Tsuji et al. 1996; Lehman et al. 2005; Dos Anjos et al. 2006; Bullerjahn et al. 2016; Francy et al.

66 2016; Loftin et al. 2016; Douma et al. 2017).

In an effort to understand the potential impact of man-made activities and environmental

conditions in the study location on water quality, we attempted to correlate water quality parameters measured in our own laboratory or obtained from the USEPA's STOrage and RETrieval (USEPA 2016) and Water Quality eXchange databases with cyanobacterial toxin concentrations in a reservoir.

\section{Materials and Methods}

\section{Chemicals and Consumables}

Methanol, acetonitrile, formic acid, ammonium formate, and water (all LC/MS or Optima grade) were obtained from Fisher Chemicals (Fair Lawn, NJ). Ammonium hydroxide $\left(\mathrm{NH}_{3}\right.$ content 28-30\%; analytical grade) was from Sigma-Aldrich (St. Louis, MO). Solid phase extraction (SPE) cartridges were 60-mg Oasis HLB with 30- $\mu \mathrm{m}$ particle size (Waters, Milford, MA). Borosilicate glass tubes, autosample vials, and polypropylene centrifuge tubes were purchased from Fisher Scientific. Milli Q water (>18 M $)$ ) was produced from a water purification system (Barnstead Nanopure, USA). Multi-anion standards were from SigmaAldrich (USA) and multi-cation standards were from Alltech (USA). Anatoxin-a, microcystinLA, -LR, and -RR standards, as well as saxitoxin and cylindrospermopsin ELISA kits were all 
84 from Abraxis (PA, USA). The 25-mm glass microfiber GF/A syringe filters were obtained from

85 Whatman (GE Healthcare UK Limited, UK) and B-D 10-mL disposable syringes were from

86 Becton Dickinson \& Co (NJ, USA). The IC eluents were sodium hydroxide $(50 \%$, w/w) for

87 anion analysis and methanesulfonic acid for cation analysis.

88

89

90

91

\section{Sample collection}

Water samples were collected from nine different locations within a recreational reservoir in the southwest U.S. at monthly intervals from September 2015 to September 2017. The lake is 89,000 acres in area and holds $>2.5$ million acre- $\mathrm{ft}$ of water. The minimum distance between sample locations was one mile. The collected 500-mL water samples were stored in airtight amber containers and kept on dry ice until transport to our laboratories in Lubbock, TX within 24 h.

\section{Sample pre-treatment}

The analysis of algal toxins in collected water was initiated immediately after receipt of samples. Frozen water samples were thawed, then sonicated for $3 \mathrm{~h}$. An aliquot of each sample was collected for use while the remaining sample volume was stored in the freezer at $-20{ }^{\circ} \mathrm{C}$ prior to inorganic ion analysis.

\section{Saxitoxin and Cylindrospermopsin Analysis by ELISA}

For the ELISA tests, we followed the methods provided by the manufacturer (Abraxis, Inc, 2019a; 2019b). The 96-well plates were tested using a UV-VIS spectrophotometer (Spectra Max Plus, Molecular Devices, USA) at $450 \mathrm{~nm}$. 


\section{Anatoxin-a, Microcystin-LR, -LA, and -RR determination by LC-MS/MS}

$20 \mathrm{~mL}$ of pre-filtered water sample was aliquoted into a 50-mL polypropylene tube. In parallel, a laboratory blank sample (Milli-Q water), a laboratory control sample (LCS; spiked Milli-Q water), and a matrix-spike sample (MS) were also prepared for quality control. LCS and MS were spiked with Anatoxin-a, Microcystin -LR, -LA, and -RR each at $0.5 \mathrm{ng} / \mathrm{mL} .0 .5 \mathrm{~mL}$ of methanol and $0.1 \mathrm{~mL}$ of ammonium hydroxide were added to samples. Samples were vortexed and centrifuged at 3,000 rpm for $15 \mathrm{~min}$. Oasis HLB cartridges (Waters) were conditioned using $5 \mathrm{~mL}$ of methanol followed by $5 \mathrm{~mL}$ of water. Samples were passed through the cartridges at a flow rate of 2-3 $\mathrm{mL} / \mathrm{min}$. HLB cartridges were then dried under high vacuum for $20 \mathrm{~min}$.

Cartridges were eluted $3 \mathrm{X}$ with $0.7 \mathrm{~mL}$ of $2 \%$ formic acid in methanol. Eluates were collected in glass tubes, evaporated under nitrogen, and reconstituted to $0.2 \mathrm{~mL}$ with $0.19 \mathrm{~mL}$ of methanol and $0.01 \mathrm{~mL}$ of $10 \mu \mathrm{g} / \mathrm{mL}$ simeton as an internal standard. The method used in this study followed Cong et al. (2006) and a Waters Application Note (2014). Spike-recovery tests with algal toxins met QA criteria (50\%-150\%) as described by Shoemaker et al. (2015).

Algal toxins in samples were analyzed using a Thermo Scientific Accela ultra-highperformance liquid chromatography (UHPLC) system equipped with a Thermo Scientific TSQ Quantum Access Max triple stage quadrupole mass spectrometer (MS/MS) operated in heated electrospray ionization (HESI probe) mode with positive polarity. $1 \mu \mathrm{g} / \mathrm{mL}$ algal toxin standards were used for optimization to achieve consistent counts per second (cps) in MS (Q1) and MS/MS 127 (Q3) scans. The parent and product ion transitions and other mass spectrometry operating parameters are in Supplemental Information (Tables S1 and S2). Chromatographic separation was carried out using an Accela 1250 binary pump, a CTC PAL autosampler system, a 
130 Phenomenex Nx $3 \mu 150 \mathrm{~mm}$ x $2 \mathrm{~mm}$ diameter analytical column with a SecurityGuard ULTRA

131 guard column. The column oven temperature was set to $30^{\circ} \mathrm{C}$. Elution solvents were $5 \mathrm{mM}$

132 ammonium formate and $0.1 \%$ formic acid in water:acetonitrile (95:5) (A) and $5 \mathrm{mM}$ ammonium

133 formate and $0.1 \%$ formic acid in acetonitrile:methanol (50:50) (B). The mobile phase

134 composition $(\mathrm{A}: \mathrm{B} ; \mathrm{v} / \mathrm{v})$ was $90: 10$ at $0 \mathrm{~min}, 90: 10$ at $3 \mathrm{~min}, 10: 90$ at $6 \mathrm{~min}, 10: 90$ at $10 \mathrm{~min}$, and

$13590: 10$ from 12 to $15 \mathrm{~min}$ with a flow rate of $300 \mu \mathrm{L} / \mathrm{min}$ and an injection volume of $20 \mu \mathrm{L}$. The

136 LC-MS/MS instrument software was Xcalibur version 2.1.0.

137

138

139

140

141

142

143

144

145

146

147

148

149

150

151

152

\section{Anions and cations by ion chromatography (IC)}

Water samples were diluted 1:5 with Milli-Q water, filtered $(0.45 \mu)$ and transferred to IC poly vials with filter caps. Simultaneously, a laboratory blank sample (Milli-Q water) and an LCS (Milli-Q water spiked with anions and cations) were prepared for quality control. Samples were analyzed by Dionex IC 25 Ion Chromatograph (Chromeleon software version CM 6.5 SP1) coupled with a conductivity detector (Hautman et al. 1997). Target ions were fluoride $\left(\mathrm{F}^{-}\right)$, chloride $\left(\mathrm{Cl}^{-}\right)$, bromide $\left(\mathrm{Br}^{-}\right)$, nitrate $\left(\mathrm{NO}_{3}^{-}\right)$, sulfate $\left(\mathrm{SO}_{4}{ }^{2-}\right)$, sodium $\left(\mathrm{Na}^{+}\right)$, ammonium $\left(\mathrm{NH}_{4}^{+}\right)$, potassium $\left(\mathrm{K}^{+}\right)$, magnesium $\left(\mathrm{Mg}^{2+}\right)$, and calcium $\left(\mathrm{Ca}^{2+}\right)$. The column and instrumental parameters are presented in Supplemental Information (Table S3). Spike-recovery tests with test analytes met QA criteria (85\%-115\%) as described in U.S. EPA Method 300.1 (Hautman et al. 1997).

\section{Data analysis}

Inorganic ion data for water samples were normally distributed, however, data for algal toxins were not normal and followed a typical pattern (logarithmic) for environmental residues 
153 where non-detects are frequent. The p-values for correlation analyses were determined by either

154 ANOVA or the Mann-Whitney-Wilcoxon test in R.

155

156

\section{Results and Discussion}

157

158

159

160

161

162

163

164

165

166

167

168

169

170

171

172

173

174

175

\section{Cyanobacterial toxins in surface water}

A summary of the results obtained from the analysis of freshwater lake samples for cyanobacterial toxins is presented in Table 1. Toxin concentrations during the study period never exceeded safety limits $(0.3-1.6 \mu \mathrm{g} / \mathrm{L}$ for microcystins and $0.7-3 \mu \mathrm{g} / \mathrm{L}$ for cylindrospermopsin). Toxin concentrations at levels above the limit of quantitation were infrequent during the 2-year sampling period; non-detects (ND) were common. Microcystin-LA was the least frequently detected analyte ( 86 of 89 samples were ND), followed by the other microcystins (microcystin-RR: 80 of 89 samples were ND, microcystin-LR: 77 of 89 samples were ND). Cylindrospermopsin and saxitoxin were the most frequently detected analytes above the detection limit. Although saxitoxin was frequently detected, it was never above the reporting limit or quantitation limit $(0.025 \mu \mathrm{g} / \mathrm{L})$ in any sample.

\section{Relationships between water quality parameters and cyanobacterial toxins}

Results of correlation analyses between water parameters and cyanobacterial toxin concentrations are presented in Table 2. Anatoxin-A concentrations in water samples were inversely related to $\mathrm{F}^{-}, \mathrm{Cl}^{-}, \mathrm{Br}^{-}, \mathrm{NO}_{3}^{-}, \mathrm{SO}_{4}^{-2}, \mathrm{Na}^{+}, \mathrm{NH}_{4}^{+}$, conductivity, total dissolved solids (TDS), and dissolved oxygen (DO), but directly related to $\mathrm{Ca}^{+2}, \mathrm{pH}$, water temperature, turbidity, and total phosphorus. Microcystin-LR concentrations were the least correlated with water parameters; M-LR was inversely related to alkalinity and directly related to total suspended 
176 solids (TSS), turbidity, and total phosphorus. Microcystin-LA concentrations in water samples

177 were inversely related to $\mathrm{F}^{-}, \mathrm{Cl}^{-}, \mathrm{SO}_{4}^{-2}, \mathrm{Na}^{+}$, and $\mathrm{NH}_{4}^{+}$, but directly related to turbidity, and total

178 phosphorus. Microcystin-RR concentrations in water samples were inversely related to $\mathrm{Cl}^{-}, \mathrm{Br}^{-}$,

$179 \mathrm{NO}_{3}^{-}, \mathrm{SO}_{4}^{-2}, \mathrm{Na}^{+}, \mathrm{NH}_{4}^{+}$, conductivity, alkalinity, and TDS, but directly related to $\mathrm{Ca}^{+2}$, water

180 temperature, TSS, and turbidity. Cylindrospermopsin and saxitoxin concentrations in water

181 samples were inversely correlated with $\mathrm{Mg}^{+2}$ and directly correlated with water temperature.

182 Overall, water turbidity appeared to be the best predictor of cyanobacterial toxin

183 concentrations; cylindrospermopsin concentrations were lower with increases in turbidity and

184 microcystins and anatoxin were higher with increases in turbidity. The direct relationship

185 between toxin concentrations and turbidity is surprising given that increases in turbidity would

186 reduce light penetration and presumably cyanobacterial growth (Ota et al. 2015; Wells et al.

187 2015; Ashraful Islam and Beardall, 2017). Perhaps toxin-producing cyanobacteria are out-

188 competing other species under the reduced light conditions. Increases in anatoxin, M-RR,

189 cylindrospermopsin, and saxitoxin concentrations also correlated with increases in water

190 temperature, consistent with higher cyanobacterial growth rates at higher water temperatures

191 (Butterwick et al., 2005; Watkinson et al., 2005).

192

Nutrients appear to play an important role in cyanobacterial blooms, particularly $\mathrm{N}$ and $\mathrm{P}$

193 (Filstrup and Downing, 2017). Unfortunately, the relationship between blooms and the presence

194 of cyanobacterial toxins in the water is less consistent. Complicating these relationships (and

195 attempts at correlations) are observations indicating that factors such as salinity not only

196 influence the uptake of P by cyanobacteria (Markou et al. 2014), salinity may also stimulate the

197 release of extracellular toxins (Preece et al. 2017). 

freshwater inputs.

\section{Conclusions}

Cyanobacterial toxin concentrations during the study period never exceeded safety limits. detection limit; their concentrations were directly related to water temperature in the lake and inversely related to $\mathrm{Mg}^{+2}$ concentrations in lake water. Microcystin and anatoxin concentrations were inversely correlated with $\mathrm{Cl}^{-}, \mathrm{SO}_{4}{ }^{-2}, \mathrm{Na}^{+}$, and $\mathrm{NH}_{4}{ }^{+}$, and directly correlated with turbidity 214 and total $\mathrm{P}$.

\section{Acknowledgement}


222

223

224

225

226

227

228

229

230

231

232

233

234

235

236

237

238

239

240

241

242

\section{References}

Abraxis, Inc, 2019a, Cylindrospermopsin ELISA (Microtiter Plate), Product No. 522011, accessed March 2019, at https://www.abraxiskits.com/wpcontent/uploads/2016/08/Cylindrospermopsin-User-guide-522011.pdf.

Abraxis, Inc, 2019b, Saxitoxin (PSP) ELISA, Microtiter Plate, Product No. 52255B, accessed March 2019, at https://www.abraxiskits.com/wp-content/uploads/2017/03/SaxitoxinUsers-Guide.pdf.

Ashraful Islam M, Beardall, J. 2017. Growth and Photosynthetic Characteristics of Toxic and Non-Toxic Strains of the Cyanobacteria Microcystis aeruginosa and Anabaena circinalis in Relation to Light. Microorganisms 5(45):1-13. DOI: 10.3390/microorganisms5030045

Backer LC, Manassaram-Baptiste D, LePrell R, Bolton B. 2015. Cyanobacteria and algae blooms: Review of health and environmental data from the harmful algal bloom-related illness surveillance system (HABISS) 2007-2011. Toxins 7:1048-1064. DOI: 10.3390/toxins7041048.

Breitbarth E, Oschlies A, LaRoche J. 2007. Physiological constraints on the global distribution of Trichodesmium - effect of temperature on diazotrophy. Biogeosciences 4:53-61. DOI: $10.5194 /$ bg-4-53-2007.

Bruno M, Fiori M, Mattei D, Melchiorre S, Messineo V, Volpi F, Bogialli S, Nazzari M. 2006. ELISA and LCMS/MS methods for determining cyanobacterial toxins in blue-green algae food supplements. Natural Product Research 20:827-834. DOI: $10.1080 / 14786410500410859$. 
243 Bullerjahn GS, McKay RM, Davis TW, Baker DB, Boyer GL, D’Anglada LV, Doucette GJ, Ho

JC, Irwin EG, Kling CL, Kudela RM, Kurmayer R, Michalak AM, Ortiz JD, Otten TG, Paerl HW, Qin B, Sohngen BL, Stumpf RP, Visser PM, Wilhelm SW. 2016. Global solutions to regional problems: Collecting global expertise to address the problem of harmful cyanobacterial blooms. A Lake Erie case study. Harmful Algae 54:223-238. DOI: 10.1016/j.hal.2016.01.003.

Butterwick C, Heaney SI, Talling JF. 2005. Diversity in the influence of temperature on the growth rates of freshwater algae, and its ecological relevance. Freshwater Biology 50:291-300. DOI: 10.1111/j.1365-2427.2004.01317.x.

Carpenter SR, Bolgrien D, Lathrop RC, Stow CA, Reed T, Wilson MA. 1998. Ecological and economic analysis of lake eutrophication by nonpoint pollution. Australian Journal of Ecology 23:68-79. DOI: 10.1111/j.1442-9993.1998.tb00706.x.

Cong L, Huang B, Chen Q, Lu B, Zhang J, Ren Y. 2006. Determination of trace amount of microcystins in water samples using liquid chromatography coupled with triple quadrupole mass spectrometry. Analytica Chimica Acta 569:157-168. DOI: 10.1016/j.aca.2006.03.052.

Dodds WK, Bouska WS, Eitzmann JL, Pilger TJ, Pitts KL, Riley AJ, Schloesser JT, Thronbrugh DJ. 2009. Eutrophication of U.S. freshwaters: Analysis of potential economic damages. Environmental Science and Technology 43:12-19. DOI: 10.1021/es801217q.

Dos Anjos FM, Bittencourt-Oliveira MD, Zajac MP, Hiller S, Christian B, Erler K, Luckas B, Pinto E. 2006. Detection of harmful cyanobacteria and their toxins by both PCR amplification and LC-MS during a bloom event. Toxicon 48:239-245. DOI: 10.1016/j.toxicon.2006.05.006. 
266 Douma M, Ouahid Y, Loudiki M, del Campo FF, Oudra B. 2017. The first detection of

267

268

269

270

271

272

273

274

275

276

277

278

279

280

281

282

283

284

285

286

287

288

potentially toxic Microcystis strains in two Middle Atlas Mountains natural lakes

(Morocco). Environmental Monitoring and Assessment 189:39. DOI: 10.1007/s10661016-5753-x.

Drobac D, Tokodi N, Lujić J, Marinović Z, Subakov-Simić G, Dulić T, Važić T, Nybom S, Meriluoto J, Codd GA, Svirčev Z. 2016. Cyanobacteria and cyanotoxins in fishponds and their effects on fish tissue. Harmful Algae 55:66-76. DOI: 10.1016/j.hal.2016.02.007.

Filstrup CT, Downing JA. 2017. Relationship of chlorophyll to phosphorus and nitrogen in nutrient-rich lakes. Inland Waters 7:385-400. DOI:10.1080/20442041.2017.1375176.

Flores E, Frías JE, Rubio LM, Herrero A. 2005. Photosynthetic nitrate assimilation in cyanobacteria. Photosynthesis Research 83:117-133. DOI: 10.1007/s11120-004-5830-9.

Francy DS, Brady AMG, Ecker CD, Graham JL, Stelzer EA, Struffolino P, Dwyer DF, Loftin KA. 2016. Estimating microcystin levels at recreational sites in western Lake Erie and Ohio. Harmful Algae 58:23-34. DOI: 10.1016/j.hal.2016.07.003.

Gobler CJ, Burkholder JM, Davis TW, Harke MJ, Johengen T, Stow CA, Van de Waal DB. 2016. The dual role of nitrogen supply in controlling the growth and toxicity of cyanobacterial blooms. Harmful Algae 54:87-97. DOI: 10.1016/j.hal.2016.01.010.

Harke MJ, Davis TW, Watson SB, Gobler CJ. 2016. Nutrient-controlled niche differentiation of Western Lake Erie cyanobacterial populations revealed via metatranscriptomic surveys. Environmental Science and Technology 50:604-615. DOI: 10.1021/acs.est.5b03931.

Hautman DP, Munch D, Pfaff JD. 1997. US EPA Method 300.1: Determination of inorganic anions in drinking water by ion chromatography. EPA/600/R-98/118, NTIS PB98$169196 \mathrm{INZ}$.

Peer] reviewing PDF | (2019:01:34614:1:0:NEW 30 May 2019) 
289 Hodoki Y, Ohbayashi K, Kobayashi Y, Okuda N, Nakano SI. 2011. Temporal variation in

290

291

292

293

294

295

296

297

298

299

300

301

302

303

304

305

306

307

308

309

310

cyanobacteria species composition and photosynthetic activity in experimentally induced blooms. Journal of Plankton Research 33:1410-1416. DOI: 10.1093/plankt/fbr040.

Kondo F, Matsumoto H, Yamada S, Ishikawa N, Ito E, Nagata S, Ueno Y, Harada K. 1996. Detection and identification of metabolites of microcystins formed in vivo in mouse and rat livers. Chemical Research Toxicology 9:1355-1359. DOI: 10.1021/tx960085a.

Lehman PW, Boyer G, Hall C, Waller S, Gehrts K. 2005. Distribution and toxicity of a new colonial Microcystis aeruginosa bloom in the San Francisco Bay Estuary, California. Hydrobiologia 541:87-99. DOI: 10.1007/s10750-004-4670-0.

Loftin KA, Graham JL, Hilborn ED, Lehmann SC, Meyer MT, Dietze JE, Griffith CB. 2016. Cyanotoxins in inland lakes of the United States: Occurrence and potential recreational health risks in the EPA national lakes assessment 2007. Harmful Algae 56:77-90. DOI: 10.1016/j.hal.2016.04.001.

Markou G, Vandamme D, Muylaert K. 2014. Microalgal and cyanobacterial cultivation: The supply of nutrients. Water Research 65:186-202. DOI: 10.1016/j.watres.2014.07.025.

Ota M, Takenaka M, Sato Y, Smith Jr RL, Inomata H. 2015. Effects of light intensity and temperature on photoautotrophic growth of a green microalga, Chlorococcum littorale. Biotechnology Reports 7:24-29. DOI: 10.1016/j.btre.2015.05.001.

Paerl HW. 2008. Nutrient and other environmental controls of harmful cyanobacterial blooms along the freshwater-marine continuum. In: Hudnell HK, ed. Cyanobacterial harmful algal blooms: State of the science and research needs (Advances in Experimental Medicine and Biology Volume 619). New York: Springer-Verlag, 217-237. 
311 Preece EP, Hardy FJ, Moore BC, Bryan M. 2017. A review of microcystin detections in

312 estuarine and marine waters: Environmental implications and human health risk. Harmful Algae 61:31-45. DOI: 10.1016/j.hal.2016.11.006.

314

315

316

317

318

319

320

321

322

323

324

325

326

327

328

329

330

331

332

333

Robarts RD, Zohary T. 1987. Temperature effects on photosynthetic capacity, respiration, and growth rates of bloom-forming cyanobacteria. New Zealand Journal of Marine and Freshwater Research 21:391-399. DOI: 10.1080/00288330.1987.9516235.

Shoemaker JA, Tettenhorst DR, de la Cruz A. 2015. Method 544: Determination of microcystins and nodularin in drinking water by solid phase extraction and liquid chromatography/tandem mass spectrometry (LC/MS/MS). U.S. EPA, National Exposure Research Laboratory. Cincinnati, OH. pp. 1-70.

Tsuji K, Setsuda S, Watanuki T, Kondo F, Nakazawa H, Suzuki M, Harada K. 1996. Microcystin levels during 1992-95 for Lakes Sagami and Tsukui-Japan. Natural Toxins 4:189-194. DOI: $10.1002 / 19960404 \mathrm{NT} 7$.

USEPA (2016), STOrage and RETrieval Data Available on the World Wide Web (EPA STORET), Washington, D. C. [Available at https://www. epa.gov/waterdata/storage-andretrieval-and-water-quality-exchange.]

Watkinson AJ, O'Neil JM, Dennison WC. 2005. Ecophysiology of the marine cyanobacterium, Lyngbya majuscule (Oscillatoriaceae) in Moreton Bay, Australia. Harmful Algae 4:697715. DOI: 10.1016/j.hal.2004.09.001.

Wells ML, Trainer VL, Smayda TJ, Karlson BSO, Trick CG, Kudela RM, Ishikawa A, Bernard S, Wulff A, Anderson DM, Cochlan WP. 2015. Harmful algal blooms and climate change: Learning from the past and present to forecast the future. Harmful Algae 49:6893. DOI:10.1016/j.hal.2015.07.009. 
334 Waters Corporation. 2014. Microcystins in Natural Waters. In: Environmental Application

335 and Method Compendium, Waters Corporation. pp: 65.

336 [Available at http://www.waters.com/webassets/cms/library/docs/720004905en.pdf.]

337 


\section{Table $\mathbf{1}$ (on next page)}

Summary data for cyanobacterial toxin concentrations ( $\mu \mathrm{g} / \mathrm{L})$ in 89 water samples collected from a reservoir in the southwest U.S. from September 2015 to September 2017. 
1 Table 1. Summary data for cyanobacterial toxin concentrations $(\mu \mathrm{g} / \mathrm{L})$ in 89 water samples collected from 2 a reservoir in the southwest U.S. from September 2015 to September 2017.

3

\begin{tabular}{lllllll}
\hline Analyte & Mean & SD & Max & RL $\quad$ \#non-detects & \# $>$ RL & \# $<$ RL
\end{tabular}

\begin{tabular}{lllllllrr}
\hline Anatoxin-A $^{1}$ & 0.013 & 0.021 & 0.14 & 0.02 & 53 & 9 & 27 \\
7 & M-RR $^{2}$ & 0.002 & 0.010 & 0.07 & 0.05 & 80 & 3 & 6 \\
8 & M-LR $^{2}$ & 0.004 & 0.011 & 0.06 & 0.05 & 77 & 5 & 7 \\
9 & M-LA $^{2}$ & 0.003 & 0.025 & 0.24 & 0.05 & 86 & 1 & 2 \\
0 & Cylindrospermopsin $^{3}$ & 0.044 & 0.032 & 0.10 & 0.10 & 24 & 15 & 50 \\
1 & Saxitoxin $^{4}$ & 0.017 & 0.012 & NA & 0.05 & 30 & 0 & 59
\end{tabular}

12

SD - standard deviation

14 RL - reporting limit

$15{ }^{1}$ In calculating the mean, we used the detection limit $(0.025 \mu \mathrm{g} / \mathrm{L})$ for samples containing anatoxin at $<$ 16 RL and 0 for non-detect samples.

$17{ }^{2}$ In calculating the mean, we used the detection limit $(0.01 \mu \mathrm{g} / \mathrm{L})$ for samples containing microcystins at $<$ $18 \mathrm{RL}$ and 0 for non-detect samples.

$19{ }^{3}$ In calculating the mean, we used $1 / 2$ the RL $(0.05 \mu \mathrm{g} / \mathrm{L})$ for samples containing cylindrospermopsin at $<$ $20 \mathrm{RL}$ and 0 for non-detect samples.

$21{ }^{4}$ In calculating the mean, we used $1 / 2$ the $\mathrm{RL}(0.025 \mu \mathrm{g} / \mathrm{L})$ for samples containing saxitoxin at $<\mathrm{RL}$ and 0 22 for non-detect samples. 


\section{Table 2 (on next page)}

Correlation ( $p$ values) between water parameters and cyanobacterial toxin concentrations in 89 water samples collected from a reservoir in the southwest U.S. from September 2015 to September 2017. 
1 Table 2. Correlation ( $\mathrm{p}$ values) between water parameters and cyanobacterial toxin concentrations in 89

2 water samples collected from a reservoir in the southwest U.S. from September 2015 to September 2017.

3

4

5

6

$7 \mathrm{~F}^{-}$

Parameter

Anatoxin-A M-LR

M-LA

M-RR

Cylindrospermopsin

Saxitoxin

$8 \mathrm{Cl}^{-}$

$9 \mathrm{Br}^{-}$

$\downarrow\left(9.3 \mathrm{E}^{-05}\right) \quad \mathrm{NS}$

$\downarrow(0.05)$

NS

$\downarrow(0.03)$

$\downarrow(0.03)$

$\downarrow\left(1.8 \mathrm{E}^{-05}\right) \quad \mathrm{NS}$

NS

$\downarrow\left(5.0 \mathrm{E}^{-05}\right)$

NS

$\downarrow\left(2.4 \mathrm{E}^{-05}\right) \quad \mathrm{NS}$

$\downarrow(0.02)$

$\downarrow(0.01)$

$\downarrow\left(5.6 \mathrm{E}^{-07}\right) \quad \mathrm{NS}$

$\downarrow(0.01)$

$\downarrow(0.02) \quad \downarrow(0.003)$

$\downarrow(0.04) \quad \downarrow(0.01)$

$\downarrow\left(5.8 \mathrm{E}^{-09}\right) \quad \mathrm{NS}$

NS

NS

NS

NS

NS

NS

$\uparrow(0.02)$

$\uparrow\left(4.9 \mathrm{E}^{-08}\right)$

NS

$\mathrm{NS}$

NS

$\uparrow(0.03)$

$\downarrow(0.03)$

$\downarrow(0.03)$

$\downarrow(0.01)$

$\uparrow(0.02)$

$\downarrow(0.05)$

NS

NS

$\downarrow\left(3.3 \mathrm{E}^{-10}\right) \quad \mathrm{NS} \quad \mathrm{NS}$

$\uparrow\left(5.0 \mathrm{E}^{-05}\right) \quad \mathrm{NS}$

$\uparrow(0.01)$

$\uparrow\left(5.7 \mathrm{E}^{-05}\right)$

$\uparrow(0.01)$

$\uparrow(0.03)$

NS

$\downarrow(0.01)$

NS

$\uparrow\left(2.3 \mathrm{E}^{-05}\right)$

NS

NS

NS NS

NS

NS

NS

NS

$\begin{array}{ll}\text { NS } & \text { NS } \\ \text { NS } & \text { NS } \\ \text { NS } & \text { NS } \\ \text { NS } & \text { NS } \\ \text { NS } & \text { NS } \\ \text { NS } & \text { NS } \\ \text { NS } & \text { NS } \\ \text { NS } & \text { NS } \\ \downarrow(0.03) & \downarrow(0.01) \\ \text { NS } & \text { NS } \\ \text { NS } & \text { NS } \\ \uparrow(0.01) & \uparrow(0.004) \\ \text { NS } & \text { NS } \\ \text { NS } & \text { NS } \\ \text { NS } & \text { NS } \\ \text { NS } & \text { NS } \\ \downarrow(0.02) & \text { NS } \\ \uparrow(0.01) & \text { NS } \\ \text { NS } & \text { NS } \\ \text { NS } & \text { NS } \\ \text { NS } & \text { NS } \\ \text { NS } & \text { NS }\end{array}$

29

30 NS - not significant

31 Significant correlation if $\mathrm{p} \leq 0.05$

$32 \uparrow$ indicates direct (positive) correlation

$33 \downarrow$ indicates indirect (negative) correlation 